\title{
Antibiotic Activity Potentiation and Physicochemical Characterization of the Fixed Orbignya speciosa Almond Oil against MDR Staphylococcus aureus and Other Bacteria
}

\author{
Jean Ferreira Machado ${ }^{1}$, Maria do Socorro Costa ${ }^{2}$, Saulo Relison Tintino ${ }^{2}$, \\ Fábio Fernandes Galvão Rodrigues ${ }^{2}$, Camila Bezerra Nobre ${ }^{3}$, \\ Henrique Douglas Melo Coutinho ${ }^{2, *} \mathbb{D}$, José Galberto Martins da Costa ${ }^{2}$, \\ Irwin Rose Alencar de Menezes ${ }^{2}$ and Erlânio Oliveira de Sousa ${ }^{1}$ \\ 1 Technology Center, Faculty of Technology Cariri, Juazeiro do Norte 63041-190, Brazil; \\ jean.lavras@gmail.com (J.F.M.); erlaniourca@hotmail.com (E.O.d.S.) \\ 2 Department of Biological Chemistry, Regional University of Cariri, Crato 63105-000, CE, Brazil; \\ corrinha_live@yahoo.com.br (M.d.S.C.); saulorelison@gmail.com (S.R.T.); \\ fabiogalvao01@hotmail.com (F.F.G.R.); galberto.martins@gmail.com (J.G.M.d.C.); \\ irwinalencar@yahoo.com.br (I.R.A.d.M.) \\ 3 Faculty of Medicine of Juazeiro do Norte, Juazeiro do Norte 63041-190, Brazil; milinhanobre@gmail.com \\ * Correspondence: hdmcoutinho@gmail.com; Tel./Fax: (+55)-88-3102-1212
}

Received: 8 February 2019; Accepted: 15 March 2019; Published: 17 March 2019

check for updates

\begin{abstract}
Orbignya speciosa (babassu) is an important palm tree in Brazil whose fixed almond oil is used in popular medicine and especially in food, in addition to being a research target for the manufacture of biofuels. The aim of this study was to evaluate the fixed almond oil physicochemical characterization and its antibacterial activity in isolation and in association with aminoglycosides against standard and multidrug-resistant bacteria. Analyses such as water content, pH, acidity, peroxide index, relative density, and refractive index indicate the stability and chemical quality of the oil. In the oil's GC/MS chemical composition analysis, a high saturated fatty acid (76.90\%) content was observed. Lauric acid (56.28\%) and oleic acid (23.10\%) were the major oil components. In the antibacterial test, a more significant oil activity was observed against K. pneumoniae KP-ATCC 10031 (minimal inhibitory concentration $(\mathrm{MIC})=406.37 \mu \mathrm{g} / \mathrm{mL}$ ) and Staphylococcus aureus ATCC 6538 $(\mathrm{MIC}=812.75 \mu \mathrm{g} / \mathrm{mL})$, but for the other strains-including standard and multi-resistant strains-the oil presented an MIC $\geq 1024 \mu \mathrm{g} / \mathrm{mL}$. Furthermore, a synergistic effect was observed when the oil was associated with amikacin and gentamicin against S. aureus (SA-10) and an antagonistic effect was observed with amikacin against Escherichia coli. Data indicate the O. speciosa oil as a valuable nutritional source of lauric, oleic, and myristic fatty acids with an ability to modulate aminoglycoside activity.
\end{abstract}

Keywords: Orbignya speciosa; babassu; fatty acid; anti-bacterial; aminoglycosides

\section{Introduction}

The growing increase in microorganismal resistance to conventional antimicrobial drugs such as aminoglycosides has been challenging the scientific community and causing serious public health risks [1]. Aminoglycosides are a class of antibiotics which have been used to treat many bacterial infections, and possess a mechanism of action based on protein synthesis inhibition by binding to the prokaryotic $30 \mathrm{~S}$ ribosome, preventing adequate mRNA translation [2,3]. 
Aminoglycosides have a broad bactericidal spectrum, and despite their benefits in treating many infectious disorders, bacterial resistance to them has become a problem in recent decades [3]. One of the problems associated with aminoglycoside resistance is the serious toxic effects associated with high doses or chronic treatment, leading to ototoxicity and/or nephrotoxicity [4].

Due to the growing resistance against aminoglycosides, several natural plant products have been studied regarding their antibacterial and antibiotic modifying activities. These natural products can increase or decrease an antibiotic's activity, thus being an interesting tool against the resistance problem [1,4].

Orbignya speciosa (babassu) is one of the most important palms in Brazil because its parts are used to provide food, fuel, fibers, and building materials, among other purposes. The babassu mesocarp flour is widely used for the treatment of chronic wounds, colitis, duodenal ulcers, arthritis, menstrual cramps, nervous exhaustion, cellulitis, varicose veins, and tumors [5].

Babassu presents itself as an important resource that is popularly used to produce fixed oils for centuries, being a prominent species for more than 300,000 extractive families who have their main source of income from the manual fruit peeling process to remove the almond [6]. The fixed oil represents $65 \%$ of the seed, and is used for the manufacture of soaps, surfactants, and margarines [7].

The fixed babassu almond oil is usually artisanally extracted, and the generated residues are a source of organic matter that serve as a source of proteins, fibers, minerals, and vitamins [6,7]. However, the mechanical oil extraction through almond pressing is the main method used by industries and corporations, this being less aggressive than the artisanal process, which minimizes oil oxidation providing a longer shelf life and conservation [8].

With this in mind, the objective of this study was to conduct a physicochemical characterization and evaluate the antibacterial and aminoglycoside antibiotic modifying activity of the O. speciosa fixed oil obtained by cold pressing.

\section{Materials and Methods}

\subsection{Botanical Collection and Identification}

Orbignya speciosa (babassu) fruits were collected from an area in the Chapada do Araripe (Sítio Arajara), Municipality of Barbalha, Ceará, Brazil. An exsiccate (\#9709) of the species is found in the Caririense Dárdano de Andrade Lima Herbarium (HCDAL) of the Regional University of Cariri (URCA).

\subsection{Acquiring the Fixed Oil}

The fixed oil was obtained using the mechanical extraction method with discontinuous hydraulic pressing using $500 \mathrm{~g}$ of $O$. specios $a$ almonds. The sample was added to a stainless-steel cylinder and pressed for approximately $2 \mathrm{~h}$, the pressure of which was recorded by a manometer at $15 \mathrm{~T}$. The fixed oil obtained yielded $48.0 \%$ of the crude material, and was stored in a hermetically sealed amber flask and kept refrigerated.

\subsection{Physicochemical Characterization and Fatty Acid Analysis}

Physicochemical analysis was performed according to protocols described by the Instituto Adolfo Lutz [8].

Fatty acid analysis was performed as described by Pereira et al. [9]. The individual components were identified by matching their mass spectra with those of a database with the library constructed using the spectrometer (Wiley, 229) and NIST 08 using retention indices (IRs) as a pre-selection [10], as well as by visually comparing standard fragmentation to those reported in the literature [11]. 


\subsection{Antibacterial Analysis}

\subsubsection{Strains Utilized}

Standard and multidrug-resistant bacterial strains were used in the analyses. The standard strains were: Staphylococcus aureus SA-ATCC 6538, Bacillus cereus BC-ATCC 33018, Escherichia coli EC-ATCC 10536, Pseudomonas aeruginosa PA-ATCC 9027, Klebsiella pneumoniae KP-ATCC 10031, Shigella flexneri EC-ATCC 12022, and Proteus vulgaris PV-ATCC 13315. The multiresistant strains were: S. aureus SA-10 and E. coli EC-06, with resistance profiles identified in Table 1. Bacteria were maintained in blood agar base (Laboratory Difco Ltd., Franklin Lakes, NJ, USA) and cultured at $37^{\circ} \mathrm{C}$ for $24 \mathrm{~h}$ in heart infusion agar (HIA, Difco Laboratories Ltd., Franklin Lakes, NJ, USA).

Table 1. Bacterial source and antibiotic resistance profile.

\begin{tabular}{ccc}
\hline Bacteria & Source & Resistance Profile \\
\hline $\begin{array}{c}\text { S. aureus } \\
\text { (SA-10) }\end{array}$ & Surgical wound & $\begin{array}{c}\text { Cephalothin, cephalexin, cefadroxil, oxacillin, penicillin, } \\
\text { ampicillin, ampicillin + sulbactam, amoxicillin, moxifloxacin, } \\
\text { ciprofloxacin, levofloxacin, erythromycin, clarithromycin } \\
\text { azithromycin and clindamycin }\end{array}$ \\
\hline $\begin{array}{c}\text { E. coli } \\
\text { (EC-06) }\end{array}$ & Surgical wound & $\begin{array}{c}\text { Cephalothin, cephalexin, cefadroxil, ceftriaxone, cefepime and } \\
\text { ampicillin + sulbactam }\end{array}$ \\
\hline
\end{tabular}

\subsubsection{Drugs}

The drugs used were the aminoglycosides amikacin and gentamicin (Sigma Co., St. Louis, MO, USA). The drugs were prepared at the concentration of $5000 \mu \mathrm{L} / \mathrm{mL}$ and diluted in sterile water.

\subsubsection{Minimum Inhibitory Concentration Test}

The fixed oil minimal inhibitory concentration (MIC) was determined according to Pereira et al. [9]. For the assay, Eppendorf tubes were prepared using $100 \mu \mathrm{L}$ of the inoculum and $900 \mu \mathrm{L}$ of $10 \% \mathrm{BHI}$ (Brain Heart Infusion) liquid culture medium in 96-well plates filled in the numerical sense with $100 \mu \mathrm{L}$ of this solution being added to each well. Serial microdilution was then performed using $100 \mu \mathrm{L}$ of the oil, varying the concentration from 1024 to $1.0 \mu \mathrm{g} / \mathrm{mL}$. The tests were performed in triplicates, and the plates were incubated for $24 \mathrm{~h}$ at $37^{\circ} \mathrm{C}$. To read the bacterial MIC, $20 \mu \mathrm{L}$ of resazurin was added to each well, where the color of the wells were observed after $1 \mathrm{~h}$ with a color change from blue to red corresponding to microbial growth and a permanence in the blue color corresponding to the absence of growth.

\subsubsection{Antibiotic Activity Modifying Effect}

Evaluation of the fixed oil as an antibiotic activity modifier was performed according to Pereira et al. [9]. For each Eppendorf tube, $1162 \mu \mathrm{L}$ of $10 \%$ BHI was used with $150 \mu \mathrm{L}$ of the inoculum from each strain as well as the tested oil at a volume corresponding to a sub-inhibitory concentration (MIC $/ 8=128 \mu \mathrm{g} / \mathrm{mL}$ ). Controls were prepared with only $1350 \mu \mathrm{L}$ of $10 \% \mathrm{BHI}$ and $150 \mu \mathrm{L}$ of bacterial suspension. The plates were filled in numerical order, and each well received $100 \mu \mathrm{L}$ of this solution. Microdilution was performed with $100 \mu \mathrm{L}$ of each antibiotic being added up to the penultimate well and the final volumes being discarded. The tests were performed in triplicates, and the plates were incubated at $37^{\circ} \mathrm{C}$ for $24 \mathrm{~h}$ and read through the addition of resazurin.

\subsection{Statistical Analysis}

Statistical analysis of the microbiological assays was performed using the statistical program GraphPad Prism 5.0. The geometric means were analyzed by a two-way ANOVA followed by Bonferroni's post-hoc test (where $p<0.05$ was considered significant). All assays were performed in triplicate. 


\section{Results and Discussion}

\subsection{Physicochemical Oil Analysis and Fatty Acid Profile}

Results from the O. speciosa fixed almond oil physicochemical characterization are expressed in Table 2. The oil presented a moisture content of $0.90 \%$, representing a minimum percentage of non-combined water $(<1 \%)$, suggesting high oil quality and durability [12]. Water content values lower than $1.0 \%$ were observed for the babassu fixed oils in the municipalities of São Luís and Imperatriz do Maranhão, Northeast Brazil [13].

Table 2. Physicochemical properties of the fixed oils of the almond of O. speciosa.

\begin{tabular}{cc}
\hline Physicochemical Properties & Values \\
\hline Water content $(\% \mathrm{p} / \mathrm{p})$ & $0.90 \pm 0.60$ \\
$\mathrm{pH}$ & $6.41 \pm 1.00$ \\
Acidity (as oleic acid \%) & $4.60 \pm 0.95$ \\
Relative density $\left(\mathrm{g} / \mathrm{cm}^{3}\right)$ & $0.30 \pm 0.45$ \\
Peroxide index $(\mathrm{meq} / \mathrm{Kg})$ & $4.40 \pm 0.90$ \\
Refraction index $\left(40^{\circ} \mathrm{C}\right)$ & $1.46 \pm 0.25$ \\
\hline
\end{tabular}

Results are expressed with means \pm S.E.M. $(n=3)$ of experiments performed in triplicate.

The $4.60 \%$ acid value reflects stability against neutralization and the $4.40 \mathrm{meq} / \mathrm{kg}$ peroxide index value indicates greater resistance to oxidation. The $\mathrm{pH}$ value of 6.41 is an important parameter, since it indicates the inhibitory range of several bacterial strains [12]. The refraction index was 1.46, with this criterion being widely used as a quality and oil identity criterion. Fixed babassu oil samples obtained artisanally from municipalities in the state of Maranhão, Northeast Brazil, had a refractive index in the range 1.4475-1.4501 [13]. The direct density measurement found was $0.30\left(\mathrm{~g} / \mathrm{cm}^{3}\right)$.

The $O$. speciosa fixed oil constituents, their percentage composition, and their retention indices (RIs) are presented in Table 3. The oil's GC/MS chemical composition analyses allowed the identification of four constituents, corresponding to $100 \%$ of the fatty acids present. The oil was characterized by a high saturated fatty acid content (76.90\%), where lauric acid was the most representative $(56.28 \%)$, followed by myristic acid (14.38\%). The only unsaturated fatty acid identified was oleic acid (23.10\%).

Table 3. Fatty acids identified in the fixed oil of the almond of O. speciosa.

\begin{tabular}{cccc}
\hline Order & Constituents & ${ }^{*} \mathbf{R I}(\mathbf{m i n})$ & $\mathbf{\%}$ \\
\hline \multirow{3}{*}{1} & Saturated & 76.90 \\
2 & Lauric acid (C12:0) & 16.943 & 56.28 \\
3 & Myristic acid (C14:0) & 21.653 & 14.38 \\
& Palmitic acid (C16:0) & 27.706 & 6.24 \\
4 & Unsaturated & 23.10 \\
& Oleic acid (C18:1) & 31.181 & 23.10 \\
\hline \multicolumn{3}{c}{ Total identified } \\
\hline
\end{tabular}

In collaboration with these results, $O$. speciosa oil has been reported to have a predominance of saturated fatty acids and intermediate carbon chains (C6 through to C16), of which $40 \%-55 \%$ of the composition is lauric acid $[14,15]$. Due to this, the oil exhibits significant characteristics for industrial use, as it is resistant to thermal oxidation and has a low melting temperature [16].

The major constituents observed in the fixed O. speciosa oil in this study were different from those found in the hot oil extracted using an organic solvent. Darnet et al. [17] found oleic (75.7\%) and palmitic (18.9\%) acids at higher quantities in the oil. Similarly, Silva et al. [6] found oleic (74.0\%) and palmitic (16.7\%) acids as the main constituents of this oil. In contrast, unsaturated fatty acids were predominant in the oil obtained in both studies. 


\subsection{Antibacterial Activity and Antibiotic Modifying Action}

The antibacterial test results showed a more significant $O$. speciosa fixed oil activity against $K$. pneumoniae KP-ATCC 10031 (MIC $=406.37 \mu \mathrm{g} / \mathrm{mL}$ ) and S. aureus SA-ATCC $6538(\mathrm{MIC}=812.75 \mu \mathrm{g} / \mathrm{mL})$, as shown in Table 4. For the other bacterial strains, including standard and multiresistant strains, the oil had an MIC $\geq 1024 \mu \mathrm{g} / \mathrm{mL}$.

Table 4. Minimum inhibitory concentration values $(\mu \mathrm{g} / \mathrm{mL})$ of the fixed oil of the almond of $O$. speciosa.

\begin{tabular}{cc}
\hline Bacterial Strains & MIC $(\mu \mathrm{g} / \mathrm{mL})$ \\
\hline Proteus vulgaris PV-ATCC 13315 & $\geq 1024$ \\
Klebsiella pneumoniae KP-ATCC 10031 & 406.37 \\
Shigella flexneri EC-ATCC 12022 & $\geq 1024$ \\
Pseudomonas aeruginosa PA-ATCC 9027 & $\geq 1024$ \\
Escherichia coli EC-ATCC 10536 & $\geq 1024$ \\
Escherichia coli EC-06 & $\geq 1024$ \\
Bacillus cereus BC-ATCC 33018 & $\geq 1024$ \\
Staphylococcus aureus SA-ATCC 6538 & 812.75 \\
Staphylococcus aureus SA-10 & $\geq 1024$ \\
\hline
\end{tabular}

Several fixed oils have also been reported for their antibacterial potential. Costa et al. [18] showed the antibacterial activity of the fixed Caryocar coriaceum pulp (pequi) oil against several bacterial strains. Saraiva et al. [3] observed significant antibacterial activity of the pequi pulp fixed oil against $S$. aureus and E. coli multiresistant strains (MIC $=512 \mu \mathrm{g} / \mathrm{mL}$ ). The Malus sp. (macieira) seed oil also presented activity against standard E. coli and S. aureus strains (MIC $=521 \mu \mathrm{g} / \mathrm{mL}$ ) [19].

Figure 1 shows the MICs of the antibiotics and the synergistic effects of the fixed oil in association with aminoglycoside antibiotics. A significant synergistic MIC reduction effect was observed with amikacin and gentamicin against $S$. aureus (SA-10). On the other hand, a significant antagonistic effect was observed in the amikacin activity against E. coli. The oil's modifying activity over aminoglycoside antibiotics varied according to the antibiotic type associated with the oil and the bacterial strain analyzed.

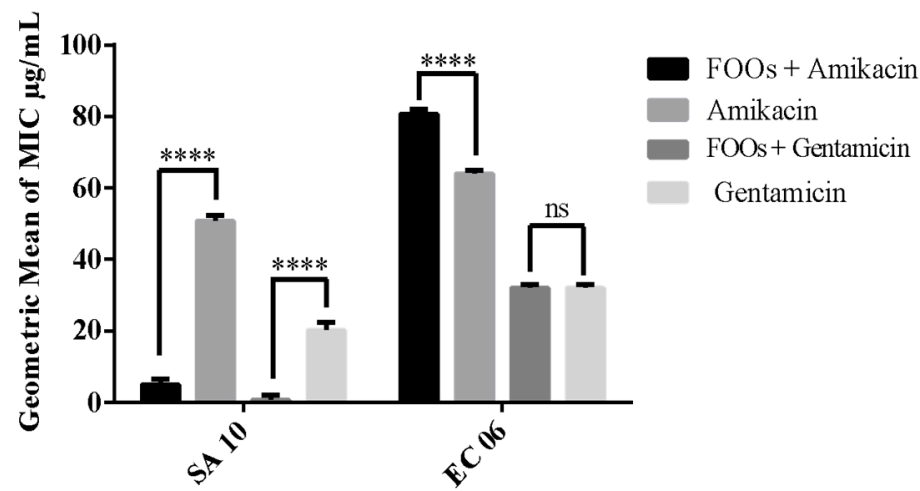

Figure 1. Effect of fixed oil of Orbignya speciosa (FOOs) on the activity of aminoglycoside antibiotics against multiresistant strains of Staphylococcus aureus (SA) and Escherichia coli (EC). Values represent the geometric mean \pm M.S.E. (mean standard error). One-way ANOVA, followed by the Bonferroni test. ${ }^{* * *}$ statistically significant value with $p<0.0001$ antibiotic + FOOs vs. control (antibiotic); ns: not statistically significant.

The fixed oil's ability to act either as an antibacterial or as an antibiotic modifier may be related to the detergent property of fatty acids against the amphipathic structure of the bacterial cell membrane. In addition, the detergent ability to solubilize membrane components (lipids and proteins) may cause breaks in this structure and affect metabolic processes essential for obtaining energy for the bacterial 
cell, such as the electron transport chain and oxidative phosphorylation. These membrane damages can also lead to difficulties with nutrient absorption, enzymatic activity inhibition, and toxic peroxidation generation $[3,20,21]$. In addition, the presence of hydrophobic compounds in the fixed oils may make the cell more permeable to antibiotics, thus increasing its efficiency and reducing the minimum concentration required to affect the bacterial cell [3], also affecting bacterial efflux pumps [22].

Many reports have demonstrated the effect of fixed oils from animals and plants enhancing antibiotic activity, such as Caryocar coriaceum, Rhinella jimi and others [3,23]. The use of oils conferring a synergistic action (MIC reduction) of antibiotics is a viable alternative, in clinical terms, against bacterial resistance.

The use of oils conferring a synergistic action (MIC reduction) of antibiotics is a viable alternative against bacterial resistance in several infectious disease cases [24]. The synergistic action of the fixed oils can occur in different ways, including a reduction in antibiotic accumulation within the bacterial cell, either by a decrease in outer membrane permeability or by drug efflux to the extracellular environment $[24,25]$.

\section{Conclusions}

The data obtained indicate the fixed O. speciosa almond oil as a valuable source of lauric, oleic, and myristic fatty acids, with a potential for modifying aminoglycoside antibiotic activity. In this sense, the use of the almonds which become residues during babassu consumption or processing, as a source for obtaining the fixed oil with the purpose of studying its antibacterial properties in isolation and in association with antibiotics is suggested.

Author Contributions: Conceptualization, S.R.T.; Formal analysis, I.R.A.d.M.; Funding acquisition, J.G.M.d.C.; Methodology, J.F.M., M.d.S.C., F.F.G.R. and C.B.N.; Project administration, H.D.M.C.; Supervision, E.O.d.S.

Funding: This research received no external funding.

Acknowledgments: The authors would like to thank the financial support provided by the FUNCAP institution.

Conflicts of Interest: The authors have declared that there is no conflict of interest.

\section{References}

1. Sousa, E.O.; Rodrigues, F.F.G.; Campos, A.R.; Costa, J.G.M. Phytochemical analysis and modulation in aminoglycosides antibiotics activity by Lantana camara L. Acta Sci. Biol. Sci. 2015, 37, 213-218. [CrossRef]

2. Hoffman, L.R.; D'Argenio, D.A.; MacCoss, M.J.; Zhang, Z.; Jones, R.A.; Miller, S.I. Aminoglycoside antibiotics induce bacterial biofilm formation. Nature 2005, 436, 1171-1175. [CrossRef]

3. Saraiva, R.A.; Matias, E.F.F.; Coutinho, H.D.M.; Costa, J.G.M.; Souza, H.H.F.; Fernandes, C.N.; Rocha, J.B.T.; Menezes, I.R.A. Synergistic action between Caryocar coriaceum Wittm. fixed oil with aminoglycosides in vitro. Eur. J. Lipid Sci. Technol. 2011, 113, 967-972. [CrossRef]

4. Lucena, B.F.F.; Tintino, S.R.; Figueredo, F.G.; Oliveira, C.D.M.; Aguiar, J.S.; Cardoso, E.N.; Aquino, P.E.A.; Andrade, J.C.; Coutinho, H.D.M.; Matias, E.F.F. Evaluation of antibacterial activity of aminoglycosides and modulating the essential oil of Cymbopogon citratus (DC.) Stapf. Acta Biol. Colomb. 2015, 20, 39-45.

5. Souza, P.A.V.R.; Palumbo, J.R.A.; Alves, L.M.; Souza, V.P.; Cabral, L.M.; Fernandes, P.D.; Takiya, C.M.; Menezes, F.S.; Nasciutti, L.E. Effects of a nanocomposite containing Orbignya speciosa lipophilic extract on Benign Prostatic Hyperplasia. J. Ethnopharmacol. 2011, 135, 135-146. [CrossRef] [PubMed]

6. Silva, S.M.; Sampaio, K.A.; Taham, T.; Rocco, S.A.; Ceriani, R.; Meirelles, A.J.A. Characterization of oil extracted from buriti fruit (Mauritia flexuosa) grown in the Brazilian Amazon region. J. Am. Oil Chem. Soc. 2009, 86, 611-616. [CrossRef]

7. Ferreira, B.S.; Almeida, C.G.; Faza, L.P.; Almeida, A.; Diniz, C.G.; Silva, V.L.; Grazul, R.M.; le Hyaric, M. Comparative properties of amazonian oils obtained by different extraction methods. Molecules 2011, 16, 5875-5885. [CrossRef]

8. Instituto Adolfo Lutz. Normas Analíticas do Instituto Adolfo Lutz: Métodos Químicos e Físicos Para Análises de Alimentos, 1st ed.; IAL: São Paulo, Brazil, 2008. 
9. Pereira, Y.F.; Costa, M.S.; Tintino, S.R.; Rocha, J.E.; Rodrigues, F.F.G.; Feitosa, M.K.S.B.; Menezes, I.R.A.; Coutinho, H.D.M.; Costa, J.G.M.; Sousa, E.O. Modulation of the antibiotic activity by Mauritia flexuosa (Buriti) fixed oil against Methicillin-Resistant Staphylococcus aureus (MRSA) and other Multidrug-Resistant (MDR) bacterial strains. Pathogens 2018, 7, 98. [CrossRef]

10. Alencar, J.W.; Craveiro, A.A.; Matos, F.J.A.; Machado, M.I.L. Kovats Indices Simulation in Essential Oil Analysis. Quim. Nova 1990, 13, 282-284.

11. Adams, R.P. Identification of Essential oil Components by Gas Chromatography/Mass Spectrometry, 4th ed.; Allured Publ. Corp: Carol Stream, IL, USA, 2007.

12. Sena, D.M., Jr.; Rodrigues, F.F.G.; Paulo, T.C.F.; Lima, S.G.; Coutinho, H.D.M.; Carvajal, J.C.L.; Costa, J.G.M. Physicochemical and spectroscopical investigation of pequi (Caryocar coriaceum Wittm.) pulp oil. Grasas y Aceites 2010, 61, 191-196.

13. Costa, C.L.; França, E.T.R.; Santos, D.S.; Costa, M.C.P.; Barbosa, M.C.L.; Nascimento, M.D.S.B. Caracterização físico-química de óleos fixos artesanais do coco babaçu (Orbignya phalerata) de regiões ecológicas do estado do Maranhão, Brasil. Rev. Pesq. Foco 2015, 20, 27-38.

14. Dzida, M.; Jezak, S.; Sumara, J.; Zarska, M.; Góralski, P. High pressure physicochemical properties of biodiesel components used for spray characteristics in diesel injection systems. Fuel 2013, 111, 165-171. [CrossRef]

15. Correia, I.M.S.; Araújo, G.S.; Paulo, J.B.A.; Sousa, E.M.B.D. Evaluation of the potential and physicochemical characteristics of Sunflower oil (Helianthus annuus L.) and Coconut (Cocos nucifera L.) produced in the Brazilian Northeast. Sci. Plena 2014, 10, 1-7.

16. Lottenberg, A.M.P. Importance of the dietary fat on the prevention and control of metabolic disturbances and cardiovascular disease. Arq. Bras. Endocrinol. Metab. 2009, 53, 595-607. [CrossRef]

17. Darnet, S.H.; Silva, L.H.M.; Rodrigues, A.M.C.; Lins, R.T. Nutritional composition, fatty acid and tocopherol contents of buriti (Mauritia flexuosa) and patawa (Oenocarpus bataua) fruit pulp from the amazon region. Food Sci. Technol. 2011, 31, 488-491. [CrossRef]

18. Costa, J.G.M.; Brito, S.A.; Nascimento, E.M.M.; Botelho, M.A.; Rodrigues, F.F.G.; Coutinho, H.D.M. Antibacterial properties of pequi pulp oil (Caryocar coriaceum-WITTM.). Int. J. Food Prop. 2011, 14, 411-416. [CrossRef]

19. Tian, H.L.; Zhan, P.; Li, K.X. Analysis of componentes and study on antioxidant and antimicrobial activities of oil in apple seeds. Int. J. Food Sci. Nutr. 2010, 61, 395-403. [CrossRef]

20. Lee, J.Y.; Kim, Y.S.; Shin, D.H. Antimicrobial synergistic effect of linolenic acid and monoglyceride against Bacillus cereus and Staphylococcus aureus. J. Agric. Food Chem. 2002, 50, 2193-2199. [CrossRef]

21. Desbois, A.P.; Smith, V.J. Antibacterial free fatty acids: Activities, mechanismsof action and biotechnological potential. App. Microbiol. Biotechnol. 2010, 85, 1629-1642. [CrossRef]

22. Chan, B.C.; Han, X.Q.; Lui, S.L.; Wong, C.W.; Wang, T.B.; Cheung, D.W.; Cheng, S.W.; Ip, M.; Han, S.Q.; Yang, X.S.; et al. Combating against methicillin-resistant Staphylococcus aureus-two fatty acids from Purslane (Portulaca oleracea L.) exhibit synergistic effects with erythromycin. J. Pharm. Pharmacol. 2015, 67, 107-116. [CrossRef]

23. Sales, D.L.; Oliveira, O.P.; Cabral, M.E.; Dias, D.Q.; Kerntopf, M.R.; Coutinho, H.D.M.; Costa, J.G.; Freitas, F.R.; Ferreira, F.S.; Alves, R.R.; et al. Chemical identification and evaluation of the antimicrobial activity of fixed oil extracted from Rhinella jimi. Pharm. Biol. 2015, 53, 98-103. [CrossRef]

24. Hemaiswarya, S.; Kruthiventi, A.K.; Doble, M. Synergism between natural products and antibiotics against infectious diseases. Phytomedicine 2008, 15, 639-652. [CrossRef]

25. Nobre, C.B.; Sousa, E.O.; Silva, J.M.F.L.; Coutinho, H.D.M.; Costa, J.G.M. Chemical composition and antibacterial activity of fixed oils of Mauritia flexuosa and Orbignya speciosa associated with aminoglycosides. Eur. J. Integr. Med. 2018, 23, 84-89. [CrossRef]

(C) 2019 by the authors. Licensee MDPI, Basel, Switzerland. This article is an open access article distributed under the terms and conditions of the Creative Commons Attribution (CC BY) license (http://creativecommons.org/licenses/by/4.0/). 